\title{
A Case for the Support of U.S. Magnet Schools of the Creative and Performing Arts
}

\author{
C. Northington Purdie \\ William Paterson University \\ USA
}

\begin{abstract}
Traditional middle and secondary schools offer a multidisciplinary approach to the curriculum with an emphasis on college and/or vocational school preparation suggesting a one-size-fits-all approach to education. There are however, over 300 public, magnet schools in the United States. One hundred thirty of those are schools for the performing and creative arts in the United States. These schools offer an alternate focus, pedagogy and modus operandi. These taxpayer-funded schools provide a haven for talented students with exceptional creativity. The millennial focus on educational has been on nontraditional, less bureaucratic charter school programs. As the Obama administration considers the allocation of funding to schools through the American Recovery and Reinvestment Act's Race for the Top Fund, support for the philosophies and practices of magnet programs (schools for the creative and performing arts in particular) should be considered. It is proposed the federal financial priorities encompass a variety of programs both old and new; specifically magnet school programs.
\end{abstract}

\section{Introduction}

Traditional middle and secondary schools offer a multidisciplinary approach to the curriculum with an emphasis on college and/or vocational school preparation. The prevalence of such schools across the country suggests a one-size-fits-all approach to education. In the United States, schools of the creative and performing arts offer an alternate educational focus, pedagogy and operating system. The specificity of services offered by these schools often necessitates a waiting list for enrollment. Many students are excluded due to limited space. The United States Department of Education refers to them as specialized magnet schools.

Support and funding should be distributed equally among all nontraditional school offerings in the U.S. as they demonstrate evidence of best practices. Both models focus on college or trade school preparation. Magnet schools of the performing arts have a long history of retention and graduation rates. They should therefore be given funding on par with new charter school programs, which are gaining momentum across the country.
Providing the same support to both charter and magnet schools would also equally distribute the selection of innovative, nontraditional school offerings across the country.

\section{Magnet Schools}

The specific designation of "magnet school" was coined in the early 1970's in response to the busing mandates towards the racial integration of schools imposed by some states. Specialized programs such as the performing arts schools were easily assimilated into the magnet model in the mid 1970's. [1] There are approximately 3600 magnet schools in operation in the United States.

Magnet schools provide a unique service in that they are distinctive and appealing in their focus. Enrollment is driven by student choice based on interest rather than by selection driven primarily by standardized testing. They draw "from a diverse range of families from throughout the community eager to enroll their children even if it means having them bused to a different and, perhaps, distant neighborhood"[1] Magnet schools offer students the opportunity to "major" in various fields such as mathematics, the science, technology, industrial arts and the creative and performing arts. In order to qualify for the designation, the schools must offer a specialty-that is not available in other area public (non charter) schools. Students who attend them must be residents of the surrounding geographic area who have chosen to attend these schools rather than the multidisciplinary school in their neighborhoods. The selection process (based on portfolio and/or audition) therefore minimizes the segregation that is evident in many urban schools. [2] The diversity of the school population reflects the wider geographic area.

The U.S. Department of Education points out that teacher turnover is significantly lower in magnet schools than in traditional schools [1]. This advantage may be due to the fact that magnet schools offer teachers the satisfaction of teaching in their areas of specialty. In traditional schools, teachers are responsible for a roster of generic multidisciplinary subjects, which are often outside of their expertise. It is argued therefore, that better teacher retention adds greater stability to the school environment. The presence of same teachers year after year in various disciplines could be viewed as a reflection of commitment to education. It would be a motivating factor and rational for students to remain in school. 
A recent study was conducted comparing the standardized test scores with students enrolled in 152 charter schools with students enrolled in 161 magnet schools in the Los Angeles, California area. Raw standardizes test scores in reading and mathematics were compiled and compared. It was found that students attending magnet schools scored higher on tests of reading and mathematics than those attending charter schools. The percentages were particularly significant for African American students. All demographics scored better on the tests than students attending traditional schools. [3]

\section{Charter Schools}

Charter schools also operate within the taxpayer funded public schools but they function independently of regulations that mandate the involvement of teacher's unions, and salary guidelines. Teachers in most charter school are not eligible for tenure. The first charter school legislation was passed in Minnesota in 1991. There are approximately 4500 charter schools in operation in the United States currently. [4]

In the American Recovery and Reinvestment Act of 2009's Race to the Top Fund, 77 billion dollars was committed to elementary and secondary education. President Obama has specified that charter schools and other innovative, nontraditional programs would be targeted for support and augmentation. This commitment promises extended funding for the startup and continuation of existing charter schools across the country. The rationale is that these programs offer "promising returns" like higher retention and graduation rates and should be given more support [5].

In the U.S. Department of Education's recent summary of ARRA, magnet schools are mentioned specifically twice (once as a potential recipient of financial incentives and the other as one example of best practices). There are however, twenty eight citations of charter schools in the document that are either successful or targeted for additional funding. The citation of magnet schools merely acknowledges the funding of one school district which their magnet program received funding under ARRA [5].

Despite the lack of recognition, magnet programs yield performance-based successes that are arguably on par with those of charter schools'. For example, many such programs have higher retention rates than traditional programs. They also boast college attendance as a positive outcome for most students [2]. It is argued that such programs offer a promising and accessible alternative to traditional education within the parameters of the existing public school format (i.e., union support, and cost effectiveness).

\section{Performing Arts Magnet Schools}

The first high school for the performing arts was established in 1948 in New York City. It gained the designation of "magnet" school roughly twenty years later. Fiorello H. La Guardia High School for the Performing Arts is arguably the most highly recognized school its type due to the feature film Fame and subsequent television showcased school life in a fictionalized version of it in the 1980's. When the film and television show ended, the national recognition of these specialty magnet high schools seemed to fade from the collective consciousness of popular culture. It is almost as if the schools ceased to exist when the television went off their air. Nothing could be further from the truth. LaGuardia High School remains however the largest performing arts school with over 2000 students attending [6].

Students choosing to attend performing arts school (both middle and secondary) must be selected from pools of hundreds of students (or thousands as in the case of LaGuardia High School). They are usually asked to audition or submit portfolios and/or examples of their written work. Once enrolled, they take the standard variety of vocational and college preparatory courses in addition to those devoted to their specific fields of study or major [6]. Courses offered in their majors are block-scheduled so that students are able to devote a longer amounts of class time on their specialties.

Public high schools for the creative and performing arts are an overlooked and undervalued influence on the career paths of thousands of adolescents across the country. There are more than 130 public taxpayer supported middle and secondary magnet schools specializing in the creative, performing and communication arts in the United States. Although they are required by law to adhere to the criteria of standardized assessments specified by the No Child Left Behind Act of 2001[7], they provide the opportunity for students to pursue interests that lie outside of those emphasized by the traditional college preparatory subject matter.

When presented with an entire student body of people who share the same basic interests, these schools are an oasis of creative and artistic exploration. Retention and graduation rates of these schools remain high. The average high school drop out rate in states that have public high schools for the performing arts is $3.8 \%$. This is lower than the national average. [2]

Graduates of such schools often become great advocates of the arts in education. A panel decides whether they are accepted into the school. These taxpayer-funded schools provide a haven for talented student who would have been overlooked or misunderstood in traditional programs. 


\section{Conclusion}

There are many tools that can remedy the problem of high drop out and retention rates in the United States. Rather than allocating preferential funding at new and innovating programs such as charter schools because they are new and virtually untried it is argued that funding priorities should encompass a variety of solutions. Despite the fact that they still rely on traditional methods of bureaucracy, magnet schools and specifically those for the performing arts should receive funding comparable to that of charter programs. Magnet programs have a long history of providing diverse, meaningful subject specific educational offerings to students across the country. They offer a viable, educational alternative option for nontraditional students.

\section{References}

[1] U.S. Department of Education, Office of Innovation and Improvement, Innovations in Education: Creating Successful Magnet School Programs, Washington, D.C., 2004.

[2] Frankenberg E., Siegel-Hawley, G. An Overlooked Model Magnet schools can successfully promote diversity as well as choice for parents and students. American School Board Journal . November, 2009.

[3] Blume, H., landsberg, M. ,Poindexter, S. Charters generally perform better than traditional schools, not as well as magnets. Los Angeles Times. January 10, 2010.

[4] Standard \& Poor's. School Matters. McGraw Hill.

[5] U.S. Department of Education American Recovery and Reinvestment Act

Report: Summary of Programs and State by State Data . Washington, D.C. November 2, 2009.

[6] Topaz, M. Something New is in the air: Arts Magnet High Schools. Dance magazine. April, 1995.

[7] U.S. Department of Education Overview: Four Pillars of No Child Left Behind. Washington, D.C. 2004. 